ARTICLE OPEN

\title{
Evidence for a volcanic underpinning of the Atlantic multidecadal oscillation
}

\author{
Sean D. Birkel ${ }^{1}$, Paul A. Mayewski ${ }^{1}$, Kirk A. Maasch ${ }^{1}$, Andrei V. Kurbatov (D) and Bradfield Lyon
}

The Atlantic multidecadal oscillation (AMO) is a 60-70 year pattern of sea-surface temperature (SST) variability in the North Atlantic commonly ascribed to internal ocean dynamics and changes in northward heat transport. Recent modeling studies, however, suggest that SSTs fluctuate primarily in response to major volcanic eruptions and changes in atmospheric circulation. Here, we utilize historical SST, atmospheric reanalysis, and stratospheric aerosol optical depth data to examine the basic evidence supporting a volcanic link. We find that cool intervals across the North Atlantic coincide with two distinct episodes of explosive volcanic activity (1880s-1920s and 1960s-1990s), where key eruptions include 1883 Krakatau, 1902 Santa María, 1912 Novarupta, 1963 Agung, 1982 El Chichón, and 1991 Pinatubo. Cool SST patterns develop in association with an increased prevalence of North Atlantic Oscillation (NAO)+ atmospheric patterns caused by stratospheric aerosol loading and a steepened poleward temperature gradient. NAO+ patterns promote wind-driven advection, evaporative cooling, and increased albedo from enhanced Saharan dust transport and anthropogenic aerosols. SSTs across the subpolar gyre are regulated by strength of low pressure near Iceland and the associated wind-driven advection of cold surface water from the Labrador Sea. This is contrary to an interpretation that subpolar SSTs are driven by changes in ocean overturning circulation. We also find that North Pacific and global mean SST declines can be readily associated with the same volcanic triggers that affect the North Atlantic. Thus, external forcing from volcanic aerosols appears to underpin multi-decade SST variability observed in the historical record.

npj Climate and Atmospheric Science (2018)1:24; doi:10.1038/s41612-018-0036-6

\section{INTRODUCTION}

Historical measurements of sea-surface temperature (SST) in the North Atlantic reveal a 60-70 year pattern of variability often described as the Atlantic multidecadal oscillation (AMO) ${ }^{1,2}$ (Fig. 1). An AMO index is defined by monthly mean basin-wide SST $\left(0^{\circ}-70^{\circ}\right.$ $\mathrm{N}, 80^{\circ} \mathrm{W}-0^{\circ}$ ) detrended and normalized to remove anthropogenic warming from the signal (Fig. 1a). Cool and warm AMO modes are identified based on the assumption that SST changes are representative of oscillatory behavior, even though the record of direct observation beginning 1851 contains only two pattern wavelengths. These AMO modes nonetheless occur in conjunction with a prevalence of atmospheric patterns resembling phases of the North Atlantic oscillation (NAO) ${ }^{3}$ (Fig. 1b). Cool AMO conditions are associated with steep poleward atmospheric gradients and strong basin-wide winds characteristic of $\mathrm{NAO}+$, whereas warm AMO conditions are associated with shallow gradients and weak winds characteristic of NAO-. This coupled atmosphere-ocean variability has important teleconnection to several systems, including rainfall over northeast Brazil and the African Sahel, ${ }^{4,5}$ and summer climate over North America and Europe. $2,6,7$ North Atlantic variability may also have strong atmospheric teleconnection to SST and sea-level pressure in the North Pacific. ${ }^{8,9}$

The precise origin of SST fluctuations represented by the AMO remains a topic of debate. ${ }^{10}$ Most previous investigations emphasize an important role of internal ocean variability and changes in northward heat transport associated with the Atlantic Meridional Overturning Circulation (AMOC).,11,12 It is suggested that freshwater injections into the subpolar gyre from glacier melt can weaken AMOC and cool the North Atlantic region. ${ }^{13,14}$ Other authors have identified important feedback and co-variability between North Atlantic SSTs, eastward transport of Saharan dust Sahel rainfall, and Atlantic hurricanes. ${ }^{15,16}$ McCarthy et al. ${ }^{17}$ show that ocean circulation responds to NAO atmospheric forcing in the region between the subpolar and subtropical gyres, thus providing a link between AMOC and the AMO. In contrast, Clement et al. ${ }^{18}$ reject the importance of AMOC altogether, and show from coupled atmosphere-ocean general circulation models (GCMs) that the AMO could develop as a pattern of variability solely from thermodynamic response of the ocean mixed layer to stochastic forcing from the middle latitude atmosphere through modes of the NAO. Other coupled GCM studies indicate that North Atlantic SST variability develops in large part from volcanic aerosol forcing (and to lesser extent solar variability), as explosive eruptions project onto the NAO and elicit ocean response from changes in atmospheric circulation and the distribution of surface winds. ${ }^{19,20}$ Coupled GCMs that incorporate robust aerosol-cloud interactions also show that anthropogenic aerosol emissions may have significant impact on SSTs. ${ }^{21}$ The volcanic-aerosol framework shares an intuitive basis with studies linking the AMO to the NAO and other wind-related mechanisms. ${ }^{15-18}$ Recent studies use the terminology Atlantic Multidecadal Variability (AMV) as a means to encompass both internal and external forcing mechanisms affecting North Atlantic climate. ${ }^{21}$ However, the term "AMO" and assumption that SSTs fluctuate by internal oscillation remain pervasive in the literature.

${ }^{1}$ Climate Change Institute and School of Earth and Climate Sciences, University of Maine, Orono, ME, USA

Correspondence: Sean D. Birkel (birkel@maine.edu)

Received: 24 July 2017 Revised: 8 May 2018 Accepted: 17 May 2018

Published online: 20 September 2018 

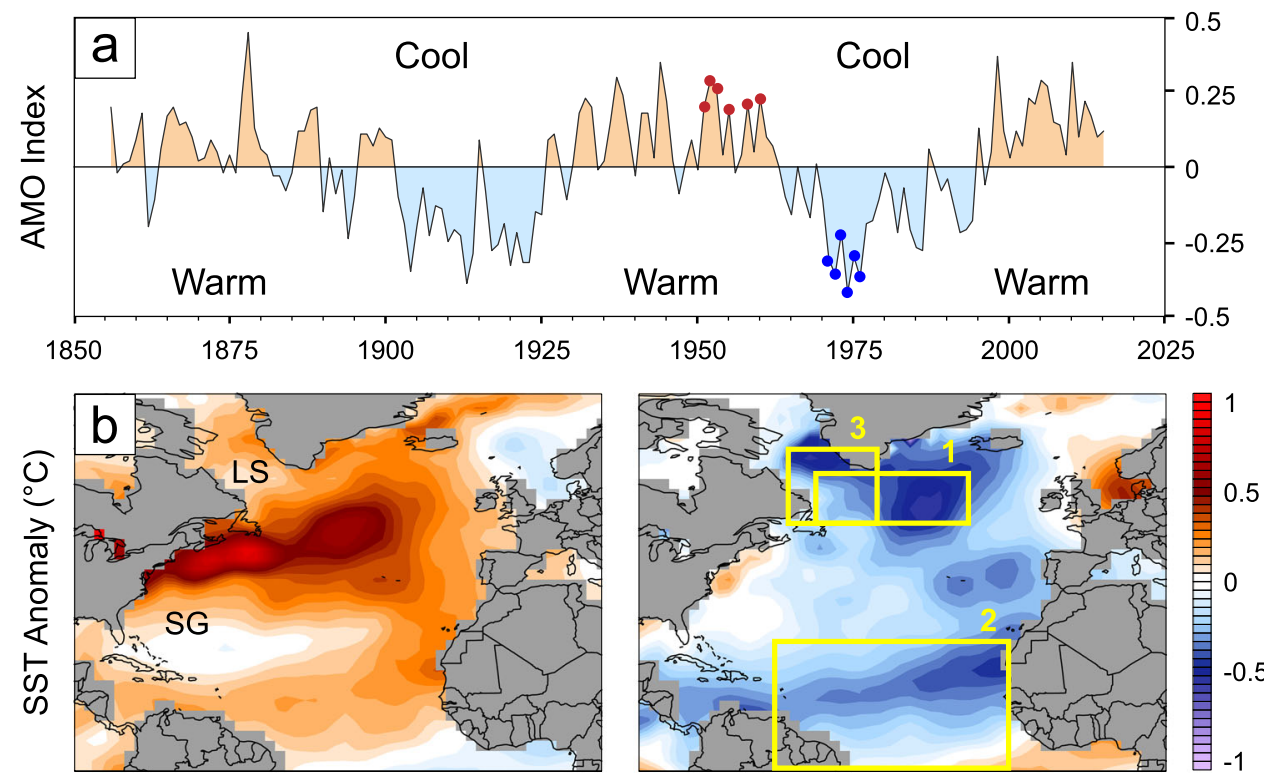

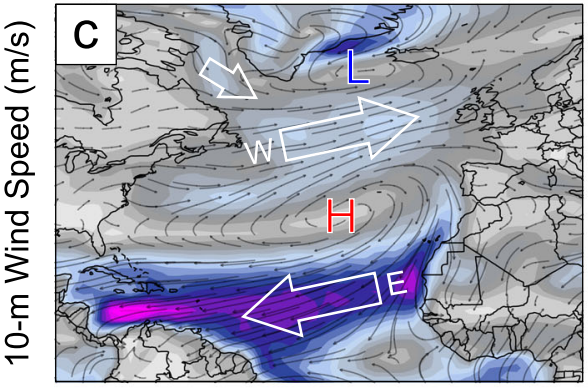

AMO-Warm

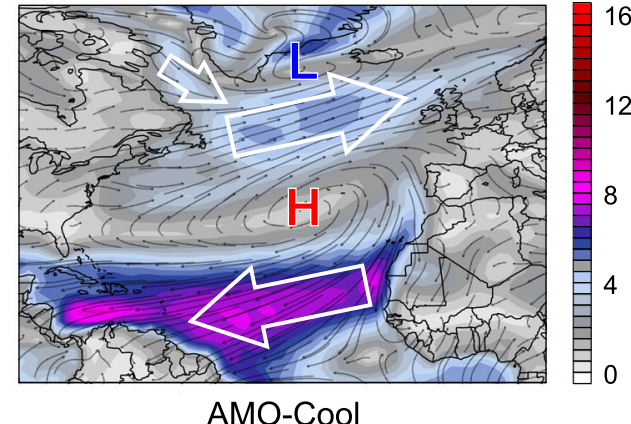

AMO-Cool

Fig. 1 Timeseries and spatial representations of the AMO. a The AMO index 1856-2015 (data from http://www.esrl.noaa.gov/psd/data/ timeseries/AMO/). Warm AMO indices shaded orange, cool indices shaded blue. Red and blue dots denote the six warmest (1951, 1952, 1953, $1955,1958,1960)$ and coolest $(1971,1972,1973,1974,1975,1976)$ years averaged to represent AMO-Warm and AMO-Cool maps shown in b and c. Modern reanalysis begins 1948. b Mean SST anomaly maps (1951-1980 climatology) for warm (left panel) and cool (right panel) years identified in a. The Labrador Sea (LS) and Sargasso Sea (SG) are labeled for reference. The boxes labeled 1-3 in the right panel of b outline the subpolar, tropical, and Labrador Sea domains referred to in Figs. 2 and 4. c Mean 10-meter wind speed maps corresponding to warm (left panel) and cool (right panel) SST anomalies in b. The Icelandic Low and Azores High are labeled L and $\mathrm{H}$, respectively, and with letters sized according to relative intensity. The middle latitude westerly and tropical easterly winds are identified by arrows and also sized according to relative intensity. Observed SST from NOAA ERSST V3b. Wind and pressure from NCEP/NCAR Reanalysis

Here, we utilize historical SST, atmospheric reanalysis, and stratospheric aerosol optical depth data to examine the basic evidence for volcanic influence on North Atlantic climate variability. By emphasizing observations, our approach provides useful information that may not be fully apparent in other related investigations that rely primarily on GCM sensitivity tests. We find that historical cool intervals across the North Atlantic coincide with two episodes of major volcanic activity (1880s-1920s and 1960s-1990s), where SST declines can be explained from the prevalence of $\mathrm{NAO}+$ atmospheric patterns that promote winddriven advection, evaporative cooling, and increased albedo from enhanced Saharan dust transport. The influence of atmospheric circulation on SST is particularly evident across the subpolar gyre, where changes in surface temperature correlate with changes in wind speed over the Labrador Sea and the pressure difference between Azores and Iceland. Looking farther afield, we also find that North Pacific and global mean SST signatures can be readily associated with volcanic forcing, where marked cooling develops after the explosive eruptions of 1883 Krakatau, 1902 Santa María, and other major volcanoes. These observations support the hypothesis that multi-decade SST variability in the North Atlantic develops primarily as a coupled atmosphere-ocean response to external forcing from volcanic aerosols.

\section{RESULTS}

North Atlantic SSTs and explosive volcanic activity

The temporal association between North Atlantic SSTs and explosive volcanic activity is shown in Fig. 2. Cool intervals coincide with significant episodic volcanic aerosol loading in the stratosphere, whereas warm intervals coincide with reduced aerosol loading, or an optically clean stratosphere. Volcanic Cool Interval (VCl) 1 begins with the well-known eruption of 1883 Krakatau, becomes entrenched after the eruption of 1902 Santa María, and then persists through the eruptions of 1907 Ksudach and 1912 Novarupta and for the next decade. VCl-2 terminates three decades of clean stratosphere and anomalous surface warmth with the eruption of 1963 Agung, and persists through the eruptions of 1968 Fernandina, 1974 Fuego, 1982 El Chichón, and 1991 Pinatubo. Warm conditions develop across the North Atlantic by the late 1990s again coincident with an optically clean stratosphere. 


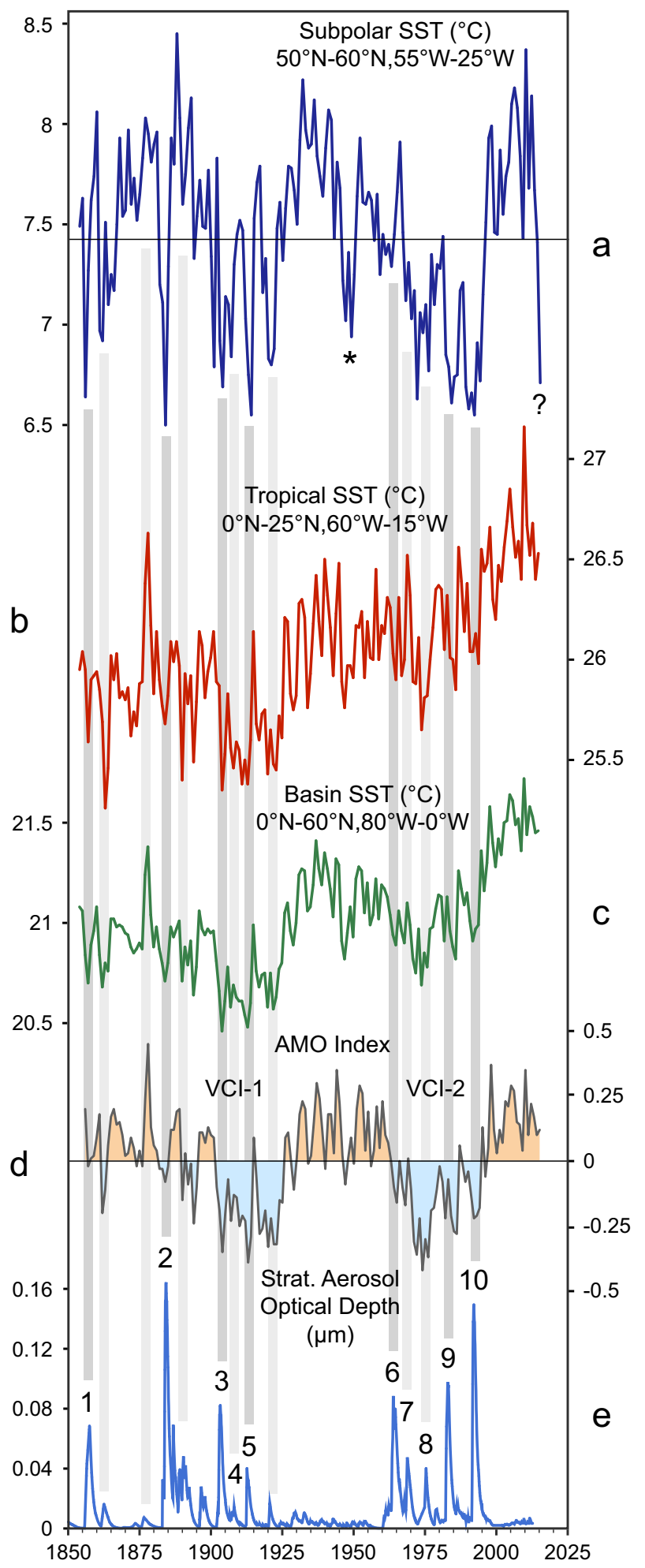

Atmospheric and SST relationships

A volcanic underpinning for North Atlantic SST variability is further deduced by examining the spatial distributions of SST and wind anomalies that arise after individual eruptions. For example, Fig. 3 shows the mean patterns that developed over three years following the explosive eruptions of 1902 Santa María and 1991 Pinatubo. Cool SST anomalies are found beneath intensified middle latitude westerlies and tropical easterlies in a tripole pattern associated with NAO + circulation. This tripole pattern is
Fig. 2 Annual mean timeseries stack for key metrics related to the AMO. a Subpolar SST $\left(50^{\circ} \mathrm{N}-60^{\circ} \mathrm{N}, 55^{\circ} \mathrm{W}-25^{\circ} \mathrm{W}\right)$. b Tropical SST $\left(0^{\circ} \mathrm{N}-\right.$ $\left.25^{\circ} \mathrm{N}, 60^{\circ} \mathrm{W}-15^{\circ} \mathrm{W}\right)$. c Basin-wide SST $\left(0^{\circ} \mathrm{N}-60^{\circ} \mathrm{N}, 80^{\circ} \mathrm{W}-0^{\circ} \mathrm{W}\right)$. d AMO index. e NASA GISS record of stratospheric aerosol optical depths at $550 \mathrm{~nm}$ for the globe ${ }^{37}$ (data from http://data.giss.nasa.gov/ modelforce/strataer/). The timeseries in $\mathbf{a}$ and $\mathbf{b}$ are averaged across the regions identified in Fig. 1. Gray columns delineate prominent volcanic peaks. The numbers in e identify eruption sources noted in Sato et al. ${ }^{37}$ and Sedlacek et al. ${ }^{39}$ and inferred from the Smithsonian Global Volcanism Program database (http://volcano.si.edu/): 1) Cotopaxi (Ecuador, 1855, VEI 3) and Awu (Indonesia, 1856, VEI 3), 2) Krakatau (Indonesia, 1883, VEl 6), 3) Santa María (Guatemala, 1902, VEI 6), 4) Ksudach (Kamchatka, 1907, VEI 5), 5) Novarupta (Aleutians, 1912, VEI 5), 6) Agung (Indonesia, 1963, VEI 5), 7) Fernandina (Galápagos Islands, 1968, VEI 4), 8) Fuego (Guatemala, 1974, VEI 4), 9) El Chichón (Mexico, 1982, VEI 5), 10) Pinatubo (Philippines, 1991, VEI 6). VEI = Volcanic Explosivity Index. Special annotations in a: $\left(^{*}\right)$ SST decline immediately after World War II that is known to be an artifact related to changes in instrumentation and measurement distribution at the end of the war; ${ }^{40}$ (?) significant SST decline for which there is not an associated volcanic aerosol spike. Observed SST from NOAA ERSST V3b

also observed in the AMO (i.e., Fig. 1). The most significant cooling occurs across the subpolar gyre (Fig. 3a), where SST anomalies can be explained by evaporative cooling and eastward advection of cold surface water into the region from the Labrador Sea, processes both driven by a deepened Icelandic Low and strengthened westerlies (Fig. 3b,c). Atmospheric forcing via wind also explains the cool SST anomalies in the tropics, where intensified easterlies cause evaporative cooling, thermocline shoaling, and increased albedo from Saharan dust entrainment. ${ }^{15,16,22,23}$ The long-term association between atmospheric circulation and SST is identified from annual timeseries plots, where subpolar SSTs co-vary with $10-\mathrm{m}$ wind speed across the Labrador Sea and the pressure difference between Azores and Iceland (Fig. 4). Likewise, strong linear correlations ( $r$ ) between the NAO index and SST and 10-meter winds are focused beneath the westerlies ( $r=-0.5$ to -0.7$)$ and easterlies $(r=-0.5$ to -0.6$)$ (Fig. $5)$, further implying important linkage between wind forcing and SST variability.

\section{Looking farther afield}

AMO-like SST signals are found in the North Pacific and in the global mean (Fig. 6). North Pacific SST fluctuations are of similar amplitude to those in the North Atlantic and include pronounced cooling during $\mathrm{VCl}-1$ and $\mathrm{VCl}-2$ (Fig. 6a). Global mean SST fluctuations have smaller amplitude, but nevertheless mimic the North Atlantic signal through VCl-1 and into the 1950s (Fig. 6b). From $\sim 1960$ onward global SSTs increase steadily. VCl-1 is well represented in all three SST signals-North Atlantic, North Pacific, and the globe-with cooling beginning after the 1883 eruption of Krakatau, SSTs bottoming between the eruptions of 1902 Santa María and 1912 Novarupta, and then relaxing to an unperturbed state by $\sim 1930 . \mathrm{VCl}-2$ is represented in the North Atlantic and North Pacific with cooling beginning after the 1963 eruption of Agung, SSTs bottoming in the mid 1970s, and then warming but with major cold departures associated with 1983 El Chichón and 1991 Pinatubo (see also comparisons in Fig. 2). The global response to explosive volcanic activity during $\mathrm{VCl}-2$ is likely muted as a consequence of increasing anthropogenic radiative impacts from the 1960s onward (Fig. 6c).

\section{DISCUSSION}

Major volcanic eruptions impact climate through radiative and chemical effects associated with sulfate aerosol clouds formed from the injection of sulfur gases into the stratosphere. ${ }^{24-26}$ The 

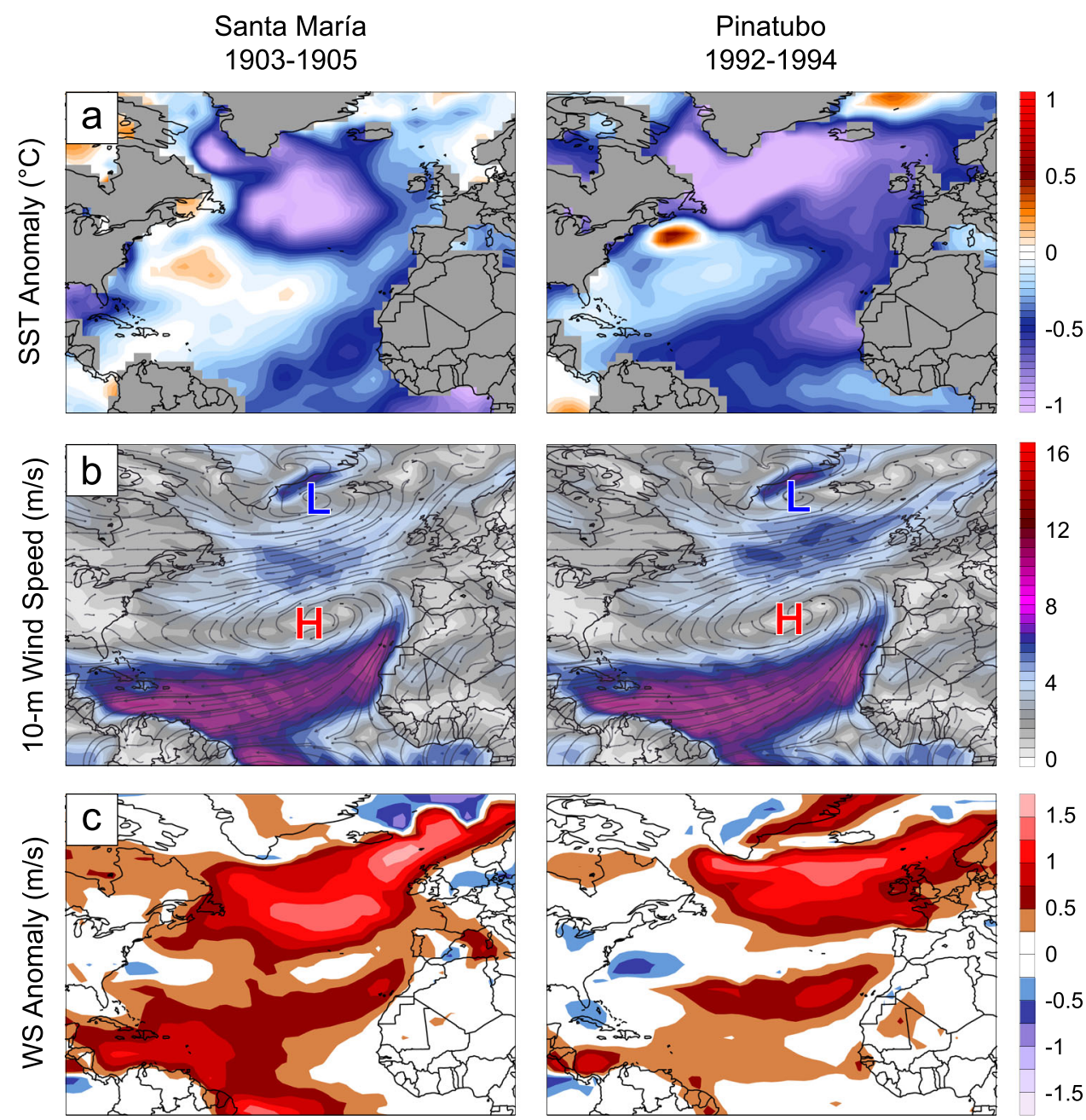

Fig. 3 North Atlantic basin-wide SST and atmospheric circulation patterns after major volcanic eruption. This example shows mean conditions that developed over three years following the eruptions of Santa María (1902) (left panels) and Pinatubo (1991) (right panels). a SST anomaly. b 10-meter wind speed. c 10-meter wind speed anomaly. Anomalies in reference to 1871-1900 and 1996-2010 climatologies for Santa María and Pinatubo, respectively. Different climate periods are used for the anomaly maps in order to compensate for the significant warming over the past century. Refer also to Supplementary Fig. S1 for anomalies derived from a detrended SST signal and 1854-2016 climatology. Observed SST from NOAA ERSST V3b. Wind and pressure from NOAA 20th Century Reanalysis

Earth surface cools directly as sulfate aerosol clouds aloft scatter a portion of incoming solar radiation back to space. Additional surface cooling can develop indirectly in response to low latitude eruptions, where aerosols concentrated over the tropics absorb both solar and terrestrial radiation, thereby heating the tropical stratosphere and creating an enhanced equator-to-pole temperature gradient. This in turn causes a poleward shift of the tropospheric jetstreams, an increase in lower tropospheric winds, and strengthening of ocean stirring in high latitudes. ${ }^{26-28}$ Global response to explosive volcanic events depends on several factors, including eruption latitude, seasonal timing, magnitude, chemical composition, duration of stratospheric disturbance (e.g., $\sim 3$ years for 1991 Pinatubo), and phasing of the El Niño Southern Oscillation (ENSO). ${ }^{26,29}$ In the Northern Hemisphere, the indirect advective response to an eruption tends to manifest as NAO+ patterns, especially during winter. ${ }^{26-30} \mathrm{NAO}+$ circulation characteristics and the associated tripole-pattern SST anomalies are also preserved in annual means (Fig. 3). The coincidence between stratospheric aerosol loading, prevalence of NAO+ atmospheric patterns, and cool SSTs across the North Atlantic (Figs. 1-2) is compelling reason to suppose that negative AMO indices sustained during the 1880s-1920s and 1960s-1990s represent a regional response to volcanic activity. The persistence of surface cooling years after a major eruption (or series of eruptions) implies that ocean-atmosphere feedbacks through mixed layer processes are important for maintaining a perturbed climate state. ${ }^{20,26,28,30}$

It has been suggested recently that SST declines across the subpolar gyre are symptomatic of an unprecedented AMOC weakening over the past century effected by Arctic melting. ${ }^{14,31}$ However, the reported ocean circulation decline occurs mostly over the interval we call VCl-2 (1960s-1990s), which encapsulates the effects of several major volcanic eruptions. Figure 4 shows that subpolar SSTs decrease during $\mathrm{VCl}-2$ in conjunction with NAO+ patterns and increasing winds that would facilitate the transport of cold surface water into the subpolar gyre from the Labrador Sea. Moreover, coupled GCM modeling experiments for the climate response to the 1815 Tambora and 1991 Pinatubo eruptions show that $\mathrm{AMOC}$ strengthens as a consequence of volcanic-induced $\mathrm{NAO}+$ atmospheric forcing, which after several years leads to a warming of the subpolar gyre surface waters. ${ }^{28}$ These results contradict the interpretation that subpolar SSTs afford a reliable proxy of AMOC strength, and highlight the uncertain linkage between overturning circulation and basin-wide climate evolution. ${ }^{18}$

There is growing agreement from studies utilizing coupled atmosphere-ocean GCMs that volcanic activity plays an important 
role in multi-decade climate variability across the North Atlantic. $^{21,32,33}$ However, low-pass filtering and other statistical techniques common in many ensemble GCM studies can mask important relationships that are apparent in the raw data. For example, significant SST declines that can be associated with volcanic aerosols are found in a multi-model historical ensemble of the Coupled Model Intercomparison Project (CMIP) version 5 (Fig. 7). The unfiltered simulated SST signals are nearly identical in

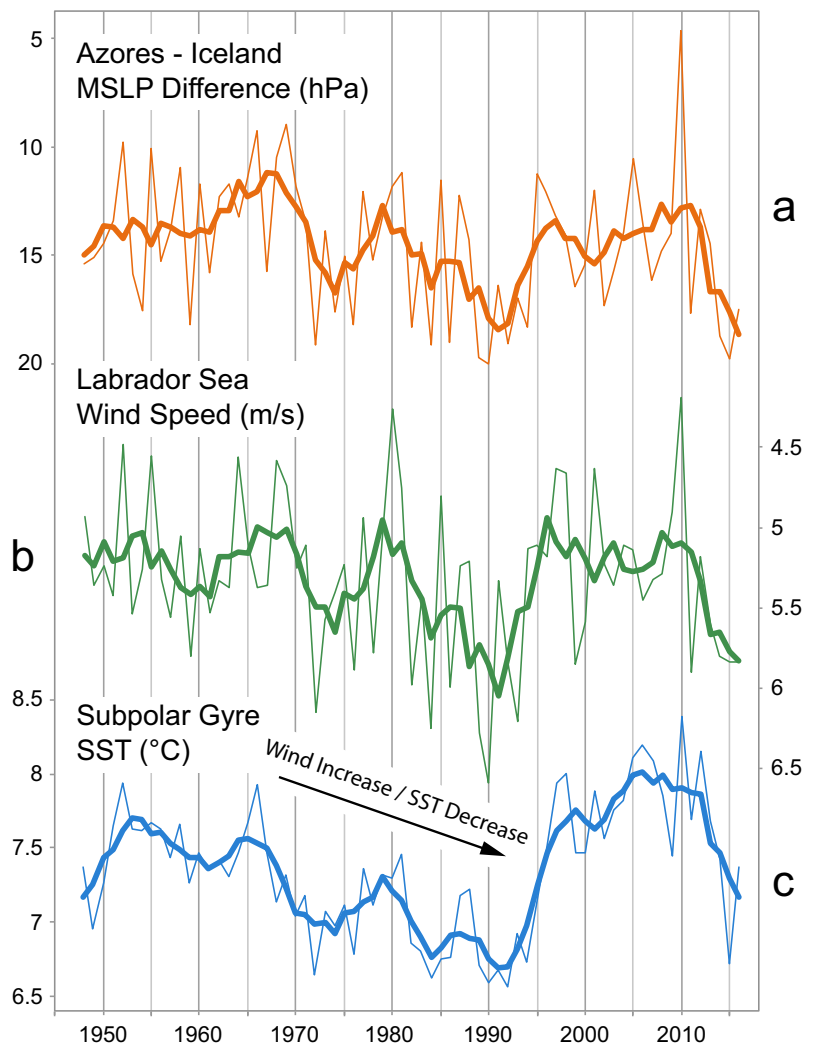

Fig. 4 Mean annual circulation metrics and SST across the subpolar North Atlantic. a Difference in mean sea level pressure (MSLP) between Azores $\left(30^{\circ} \mathrm{N}-40^{\circ} \mathrm{N}, 40^{\circ} \mathrm{W}-25^{\circ} \mathrm{W}\right)$ and Iceland $\left(60^{\circ} \mathrm{N}-65^{\circ} \mathrm{N}, 45^{\circ}\right.$ $\left.\mathrm{W}-30^{\circ} \mathrm{W}\right)$. b Wind speed at $850 \mathrm{hPa}$ over the Labrador Sea $\left(50^{\circ} \mathrm{N}-65^{\circ}\right.$ $\left.\mathrm{N}, 60^{\circ} \mathrm{W}-40^{\circ} \mathrm{W}\right)$. c SST across the subpolar gyre region south of Greenland $\left(50^{\circ} \mathrm{N}-60^{\circ} \mathrm{N}, 55^{\circ} \mathrm{W}-25^{\circ} \mathrm{W}\right)$. Bold lines represent 5-year averages. Note that $y$-axes are reversed in $\mathbf{a}$ and $\mathbf{b}$, reflecting that pressure difference and wind speed increase as SST decreases. Observed SST from NOAA ERSST V3b. Wind and pressure from NCEP/NCAR Reanalysis structure for both the North Atlantic and the global mean, where both $\mathrm{VCl}-1$ and $\mathrm{VCl}-2$ are represented by steep SST departures for each major volcanic aerosol spike, followed by rapid relaxation to the unperturbed state. In contrast, observations for both the North Atlantic and globe show that VCl-1 encompasses a gradual SST cooling after 1883 Krakatau and steep decline after 1902 Santa María, followed by gradual recovery throughout the 1920s (Fig. 6). The observed $\mathrm{VCl}-2$ has a strong SST signature in the North Atlantic (again with gradual cooling, followed warming related to anthropogenic forcing), but not in the global mean. One possible explanation for this disparity between the observed North Atlantic and global SST signals during $\mathrm{VCl}-2$ is that high anthropogenic aerosol emissions (e.g., sulfate derived from $\mathrm{SO}_{2}$ in Figs. 6 and 7) from North America and Europe, which peaked between 1960 and 1980 , contributed to regional cooling across the North Atlantic ${ }^{21}$ but had less impact on the global mean. The simulated SSTs do not reproduce this signal departure during $\mathrm{VCl}-2$. Thus, the CMIP5 models could be missing important dynamics, perhaps related to ocean circulation, albedo feedbacks, or other processes that integrate on the global scale.

Our synthesis of historical SST, reanalysis, and aerosol optical depth data is in agreement with coupled atmosphere-ocean GCM studies $^{19-21}$ linking multi-decade SST variability in the North Atlantic to explosive volcanic activity and changes in atmospheric circulation. We find that cool SST anomalies form across the basin in association with $\mathrm{NAO}+$ atmospheric patterns that tend to develop in response to volcanic aerosol loading in the stratosphere. NAO+ is an expression of steep poleward gradients and intensified atmospheric circulation that promotes wind-driven advection, evaporative cooling, and increased albedo from enhanced Saharan dust transport. The influence of wind on SSTs is most apparent across the subpolar gyre, where strength of the Icelandic Low and westerly winds can modulate the flow of cold surface water into the region from the Labrador Sea. The latter contradicts a recent interpretation ${ }^{31}$ that subpolar SSTs afford a reliable proxy of AMOC strength. The emergence of the two prominent cool intervals in the historical record, $\mathrm{VCl}-1$ (1880s-1920s) and VCl-2 (1960s-1990s), can be ascribed to the explosive eruptions of 1883 Krakatau and 1963 Agung, respectively. Subsequent major eruptions (e.g., 1902 Santa María and 1968 Fernandina) further entrenched cool conditions across the basin. It is possible that high anthropogenic aerosols emissions from North America and Europe also contributed to regional cooling across the North Atlantic during $\mathrm{VCl}-2^{21}$. Warm conditions prevail across the North Atlantic when the stratosphere is optically clean and atmospheric circulation is weak. The general timeseries associations between volcanic aerosols and SSTs also apply for North Pacific and global domains, particularly during $\mathrm{VCl}-1$ when anthropogenic impacts were relatively small. In all, we think the

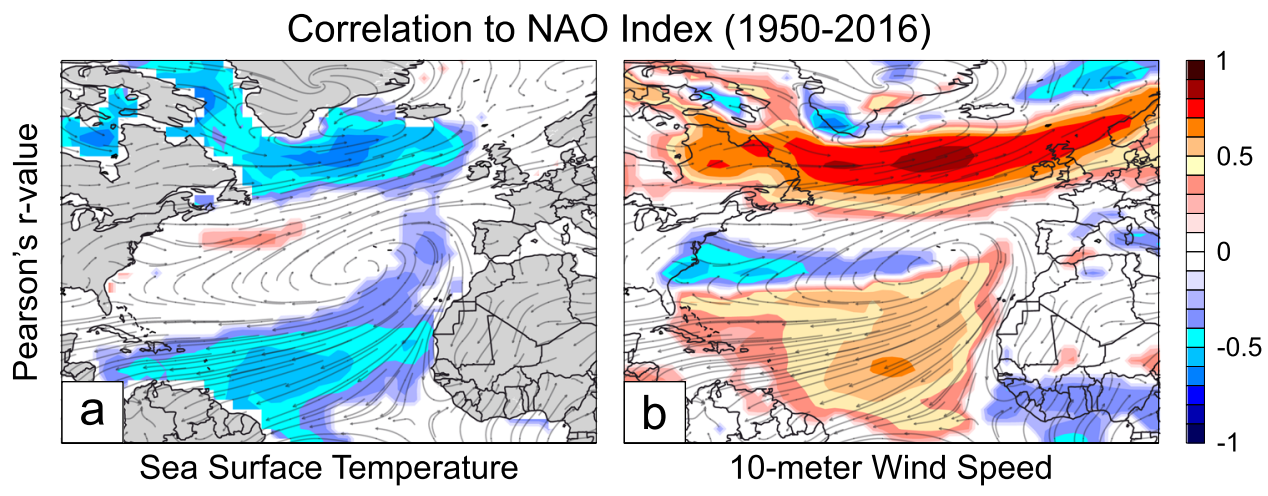

Fig. 5 Maps showing Pearson's linear correlations. a Mean-annual SST and b 10-meter wind speed are correlated against the principle component based NAO index 1950-2016. Mean-annual wind vectors for 1950-2016 are overlain. SST and atmospheric data from NCEP/NCAR Reanalysis. NAO index from the NOAA Climate Prediction Center (http://www.cpc.ncep.noaa.gov/products/precip/CWlink/pna/nao.shtml) 


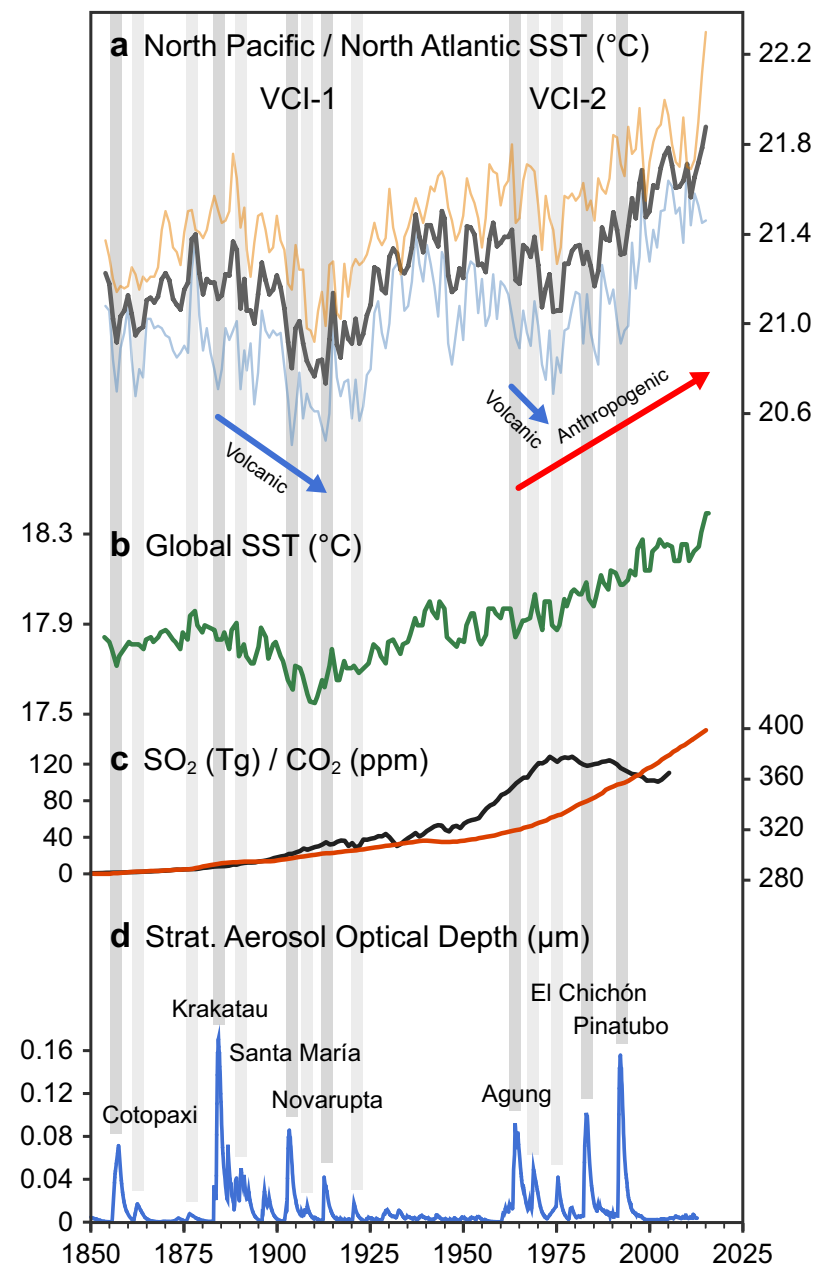

Fig. 6 Timeseries stack showing observed mean annual SST for the North Pacific, North Atlantic, and globe in relation to atmospheric $\mathrm{CO}_{2}$ concentration and volcanic aerosols. a SST for the North Pacific $\left(0^{\circ} \mathrm{N}-60^{\circ} \mathrm{N}, 120^{\circ} \mathrm{E}-255^{\circ} \mathrm{E}\right)$ (orange), North Atlantic $\left(0^{\circ} \mathrm{N}-60^{\circ} \mathrm{N}, 80^{\circ} \mathrm{W}-0^{\circ}\right.$ W) (blue), and average of the two signals (black). b SST for the globe. c Global $\mathrm{SO}_{2}$ emissions ${ }^{41}$ (black) and atmospheric $\mathrm{CO}_{2}$ concentration (orange). d Stratospheric aerosol optical depths with key eruptions labeled (refer also to Fig. 2). Colored arrows identify intervals of volcanic cooling and pronounced anthropogenic warming. Observed SST from NOAA ERSST V3b. $\mathrm{CO}_{2}$ data from NASA GISS (https://data.giss.nasa.gov/modelforce/ghgases/)

fundamental role of explosive volcanic eruptions in driving AMOlike variability should be more widely recognized in the literature.

\section{METHODS}

This study utilizes gridded atmospheric and ocean reanalysis models and stratosphere aerosol optical depth data. Near surface wind and sea level pressure are from NCEP/NCAR Reanalysis (NNR) ${ }^{34}$ for Figs. 1,4-5 and from NOAA 20th Century Reanalysis version $2(20 \mathrm{CR})^{35}$ for Fig. 2 . Reanalysis models provide numerical solutions to the state of the atmosphere from sub-daily initializations of historical weather data. NNR ingests multiple surface observations, SST, and radiosonde data beginning January 1948. 20CR ingests only surface pressure and SST, but with the benefit of utilizing historic data beginning 1871. Past weather is generally well reproduced in both NNR and 20CR owing to dense data input across the North Atlantic region over the past century. Sea surface temperature is from NOAA Extended Reconstructed SST version $3 \mathrm{~b}$ (ERSST). ${ }^{36}$ ERSST provides monthly continuous global grids of SST since 1854 derived from discontinuous observations the International Comprehensive Ocean-Atmosphere Data Set (ICOADS). ERSST solutions are generally robust across the North Atlantic for the duration of the record owing to dense ship and buoy

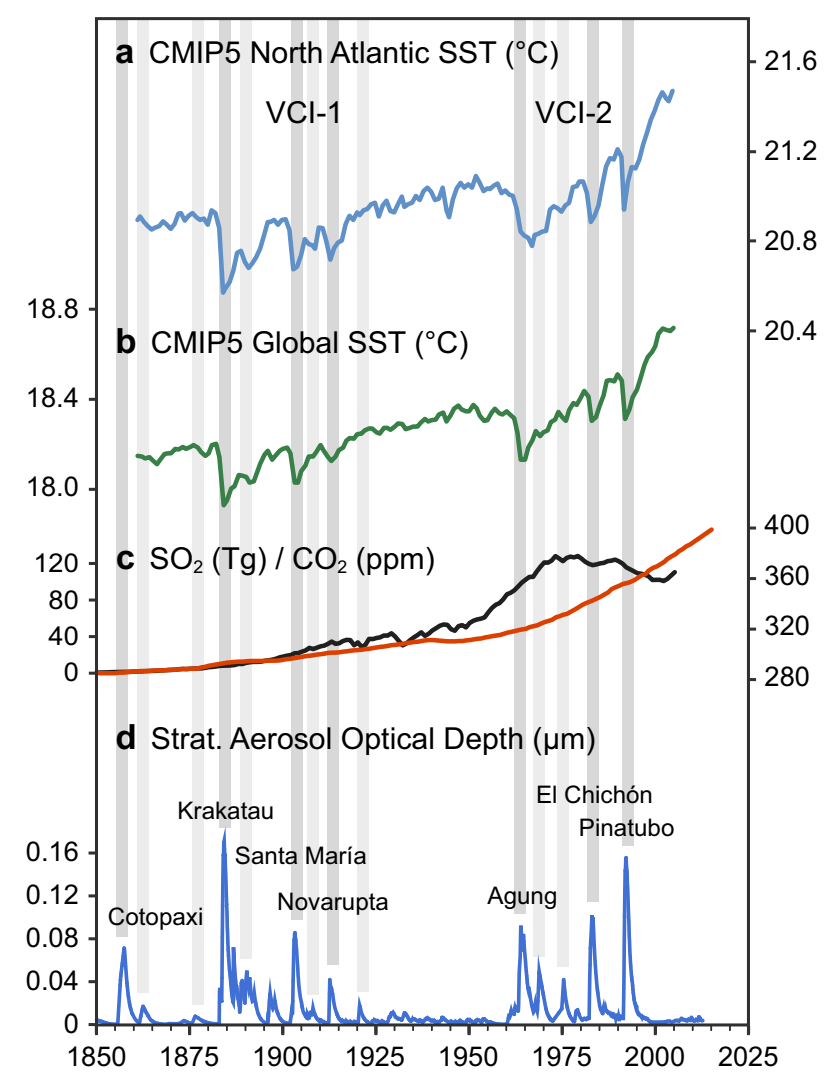

Fig. 7 Timeseries stack showing CMIP5 simulated mean annual North Atlantic and global SST in relation to atmospheric $\mathrm{CO}_{2}$ concentration and volcanic aerosols. a SST for the North Atlantic $\left(0^{\circ}\right.$ $\left.\mathrm{N}-60^{\circ} \mathrm{N}, 80^{\circ} \mathrm{W}-0^{\circ} \mathrm{W}\right)$. b SST global mean annual SST. c Global $\mathrm{SO}_{2}$ emissions $^{41}$ (black) and atmospheric $\mathrm{CO}_{2}$ concentration (orange). d Stratospheric aerosol optical depths with key eruptions labeled (refer also to Fig. 2). SST timeseries are from ensemble averages of five leading CMIP5 models (CCSM4, GFDL-CM3, GISS-E2-H-P1, HADGEM2-ES, MIROC5). $\mathrm{CO}_{2}$ data from NASA GISS (https://data. giss.nasa.gov/modelforce/ghgases/)

observations. ERSST is most reliable for both the North Atlantic and North Pacific after 1880. Stratospheric aerosol optical depth data in Fig. 2 are from Sato et al. ${ }^{37}$ and available from NASA GISS. Optical depths 1883-1990 are estimated from composite optical extinction data with increasing quality throughout the record. Optical depths 1850-1882 are from qualitative estimates of eruption data and ejecta volume for major known volcanoes, and considered less reliable than the more recent part of the record. The simulated historical SST timeseries in Fig. 7 are from a fivemember (CCSM4, GFDL-CM3, GISS-E2-H-P1, HADGEM2-ES, MIROC5) ensemble subset of the Coupled Model Intercomparison Project (CMIP) version $5 .{ }^{38}$ All spatial-temporal timeseries are produced from areaweighted averages. Data processing and analysis was carried out using NCAR Command Language (NCL).

\section{Data availability}

The data/reanalyzes that support the findings of this study are publicly available online as follows: Stratospheric aerosol optical depth and atmospheric $\mathrm{CO}_{2}$ measurements are available from NASA GISS (http:// data.giss.nasa.gov/modelforce/strataer/ and https://data.giss.nasa.gov/ modelforce/ghgases/); The NAO index is available from the NOAA Climate Prediction Center (http://www.cpc.ncep.noaa.gov/products/precip/CWlink/ pna/nao.shtml); The AMO index is available from the NOAA Earth Systems Research Laboratory (ESRL) (http://www.esrl.noaa.gov/psd/data/timeseries/ AMO/); NCEP/NCAR Reanalysis, NOAA/CIRES 20th Century Reanalysis (20CR) version 2, and NOAA Extended Reconstruction Sea Surface Temperature (ERSST) version $3 \mathrm{~b}$ data are also available from the NOAA ESRL (https:// www.esrl.noaa.gov/psd/data/gridded/); CMIP5 ensemble model area- 
weighted timeseries are available from KNMI Climate Explorer (https:// climexp.knmi.nl); Most maps, timeseries, and linear correlations presented here can be also be reproduced using Climate Reanalyzer (http://ccireanalyzer.org), a data visualization framework developed by lead author Birkel for the Climate Change Institute at the University of Maine.

\section{ACKNOWLEDGEMENTS}

Lead author S.D.B. received support for this work from the National Science Foundation (Award \#1417640) and International Center for Tropical Agriculture. We thank Dr. Alan Robock and two anonymous reviewers for helpful critique that improved this manuscript. This work utilized high-performance computing support from Yellowstone/Geyser (ark:/85065/d7wd3xhc) provided by NCAR's Computational and Information Systems Laboratory, sponsored by the National Science Foundation.

\section{AUTHOR CONTRIBUTIONS}

All authors researched, collated, and wrote this paper.

\section{ADDITIONAL INFORMATION}

Supplementary information accompanies the paper on the npj Climate and Atmospheric Science website (https://doi.org/10.1038/s41612-018-0036-6).

Competing interests: The authors declare no competing interests.

Publisher's note Springer Nature remains neutral with regard to jurisdictional claims in published maps and institutional affiliations.

\section{REFERENCES}

1. Schlesinger, M. E. \& Ramankutty, N. An oscillation in the global climate system of period 65-70 years. Nature 367, 723-726 (1994).

2. Enfield, D. B., Mestas-Nuñez, A. M. \& Trimble, P. J. The Atlantic multidecadal oscillation and its relation to rainfall and river flows in the continental US. Geophys. Res. Lett. 28, 2077-2080 (2001).

3. Grossman, I. \& Klotzbach, P. J. A review of North Atlantic modes of natural variability and their driving mechanisms. J. Geophys. Res. 114, D24107 (2009).

4. Folland, C. K., Colman, A. W., Rowell, D. P., \& Davey, M. K. Predictability of northeast Brazil rainfall and real-time forecast skill. J. Clim. 14, 1937-1958 (2001).

5. Rowell, D. P. The impact of Mediterranean SSTs on the Sahelian rainfall season. J. Clim. 16, 849-862 (2003).

6. Sutton, R. T. \& Hodson, D. L. R. Atlantic ocean forcing of North American and European summer climate. Science 309, 115-118 (2005).

7. Goldenberg, S. B., Landsea, C. W., Mestas-Nuñez, A. M. \& Gray, W. M. The recent increase in Atlantic hurricane activity: Causes and implications. Science 293, 474-479 (2001).

8. Delworth, T. L. \& Mann, M. E. Observed and simulated multidecadal variability in the Northern Hemisphere. Clim. Dyn. 16, 661-676 (2000).

9. Timmerman, A., Latif, M., Voss, R. \& Grotzner, A. Northern hemispheric interdecadal variability: a coupled air-sea mode. J. Clim. 11, 1906-1931 (1998).

10. Drinkwater, K. F. et al. The Atlantic multidecadal oscillation: its manifestations and impacts with special emphasis on the Atlantic region north of $60^{\circ} \mathrm{N}$. J. Mar. Sys. 133, 117-130 (2014).

11. Gray, W. M, Sheaffer, J. D. \& Landsea, C. W. Climate trends associated with multidecadal variability of Atlantic hurricane activity (eds Diaz, H. F. \& Pulwarty, R. S.) In Hurricanes, Climate and Socioeconomic Impacts. 15-53 (Springer, Berlin, 1997).

12. Knight, J. R., Allan, R. J., Folland, C. K., Vellinga, M. \& Mann, M. E. A signature of persistent natural thermohaline circulation cycles in observed climate. Geophys. Res. Lett. 32, L20708 (2005).

13. Zhang, R. \& Delworth, T. L. Simulated tropical response to a substantial weak ening of the Atlantic thermohaline circulation. J. Clim. 18, 1853-1860 (2005).

14. Rahmstorf, S. et al. Exceptional twentieth-century slowdown in Atlantic Ocean overturning circulation. Nat. Clim. Change 5, 475-480 (2015).

15. Foltz, G. R. \& McPhaden, M. J. Impact of Saharan dust on tropical North Atlantic SST. J. Clim. 21, 5048-5060 (2008)

16. Wang, C., Dong, S., Evan, A. T., Foltz, G. R. \& Lee, S.-K. Multidecadal covariability of North Atlantic sea surface temperature, African dust, Sahel rainfall, and Atlantic hurricanes. J. Clim. 25, 5404-5415 (2012).

17. McCarthy, G. D., Haigh, I. D., Hirschi, J. J.-M., Grist, J. P. \& Smeed, D. A. Ocean impact on decadal Atlantic climate variability revealed by sea-level observations. Nature 521, 508-510 (2015).
18. Clement, A. et al. The Atlantic Multidecadal Oscillation without a role for ocean circulation. Science 350, 320-324 (2015).

19. Otterå, O. H., Bentsen, M., Drange, H. \& Suo, L. External forcing as a metronome for Atlantic multidecadal variability. Nat. Geosci. 3, 688-694 (2010).

20. Zanchettin, D. et al. Toward predicting volcanically-forced decadal climate variability. Glob. Chang. Mag. 25, 25-31, https://doi.org/10.22498/pages.25.1.25 (2017).

21. Booth, B. B., Dunstone, N. J., Halloran, P. R., Andrews, T. \& Bellouin, N. Aerosols implicated as a prime driver of twentieth-century North Atlantic climate variability. Nature 484, 228-232 (2012).

22. Bjerknes, J. Atlantic air-sea interaction. In Advances in Geophys. Vol. 10, 1-82 (Academic Press, 1964).

23. Colin, C. \& Garzoli, S. L. In situ wind measurements and the ocean response in the equatorial Atlantic during the Programme Francais Ocean et Climat Dans l'Atlantique Equatorial and Seasonal Response of the Atlantic Ocean Experiment. J. Geophys. Res. Oceans 92, 3741-3750 (1987). (C4).

24. Newell, R. E. \& Weare, B. C. Factors governing tropospheric mean temperature. Science 194, 1413-1414 (1976).

25. Hansen, J. E., Sato, M., Kharecha, P. \& von Schuckmann, K. Earth's energy imbalance and implications. Atmos. Chem. Phys. 11, 13421-13499 (2011).

26. Robock, A. Volcanic eruptions and climate. Rev. Geophys. 38, 191-219 (2000).

27. Toggweiler, J. R. \& Russell, J. Ocean circulation in a warming climate. Nature 451, 286-288 (2008)

28. Stenchikov, G. et al. Volcanic signals in oceans. J. Geophys. Res. 114, D16104 (2009).

29. Driscoll, S., Bozzo, A., Gray, L. J., Robock, A. \& Stenchikov, G. Coupled Model Intercomparison Project 5 (CMIP5) simulations of climate following volcanic eruptions. J. Geophys. Res. 117, D17105 (2012).

30. Zielinski, G. A. Use of paleo-records in determining variability within the volcanism-climate system. Quat. Sci. Rev. 19, 417-438 (2000).

31. Caesar, L., Rahmstorf, S., Robinson, A., Feulner, G. \& Saba, V. Observed fingerprint of a weakening Atlantic Ocean overturning circulation. Nature 556, 191-196, https://doi.org/10.1038/s41586-018-0006-5 (2018).

32. Murphy, L. N., Bellomo, K., Cane, M. \& Clement, A. The role of historical forcings in simulating the observed Atlantic multidecadal oscillation. Geophys. Res. Lett. 44 2472-2480, https://doi.org/10.1002/2016GL071337 (2017).

33. Bellomo, K., Murphy, L. N., Cane, M., Clement, A. Historical forcings as main drivers of the Atlantic Multidecadal variability in the CESM large ensemble. Clim. Dyn. https://doi.org/10.1007/s00382-017-3834-3(2017).

34. Kalnay, E. et al. The NCEP/NCAR 40-year reanalysis project. Bull. Am. Meteorol. Soc. 77, 437-471 (1996).

35. Compo, G. P. et al. The twentieth century reanalysis project. Q. J. Roy. Meteorol. Soc. 137, 1-28, https://doi.org/10.1002/qj.776 (2011).

36. Smith, T. M., Reynolds, R. W., Peterson, T. C. \& Lawrimore, J. Improvements to NOAA's historical merged land-ocean surface temperature analysis (1880-2006). J. Clim. 21, 2283-2296, https://doi.org/10.1175/2007JCLI2100.1 (2008).

37. Sato, M., Hansen, J. E., McCormick, P. M. \& Pollack, J. B. Stratospheric aerosol optical depths, 1850-1990. J. Geophys. Res. 98, 22987-22994 (1993). (D12).

38. Taylor, K. E., Stouffer, R. J. \& Meehl, G. A. An Overview of CMIP5 and the experiment design. Bull. Am. Meteor. Soc. 93, 485-498, https://doi.org/10.1175/ BAMS-D-11-00094.1 (2012).

39. Sedlacek, W. A., Mroz, E. J., Lazrus, A. L. \& Gandrud, B. W. A decade of stratospheric sulfate measurements compared with observations of volcanic eruptions. J. Geophys. Res. Oceans 88, 3741-3776 (1983). (C6).

40. Thompson, D. W., Kennedy, J. J., Wallace, J. M. \& Jones, P. D. A large discontinuity in the mid-twentieth century in observed global-mean surface temperature. Nature 453, 646-649, https://doi.org/10.1038/nature06982 (2008).

41. Smith, S. J. et al. Anthropogenic sulfur dioxide emissions: 1850-2005. Atmos. Chem. Phys. 11, 1101-1116 (2011).

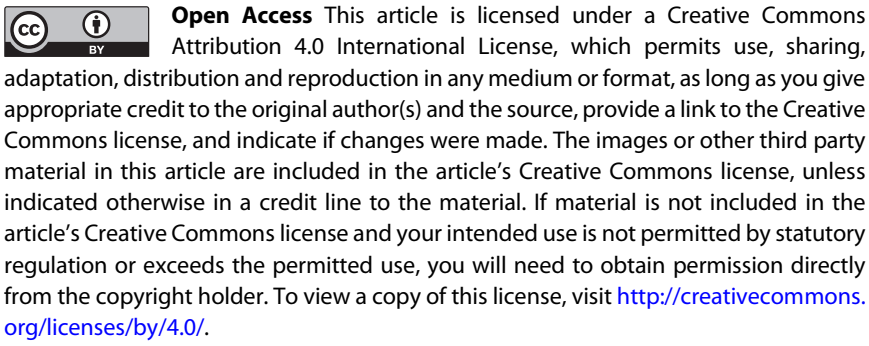

(c) The Author(s) 2018 